\title{
Maternal and fetal influences on blood pressure
}

\author{
C M Law, D J P Barker, A R Bull, C Osmond
}

\begin{abstract}
To study maternal and fetal influences on blood pressure in childhood 405 children aged 4 years who were born and still resident in the Salisbury health district were visited at home for blood pressure and growth measurements. Information on the pregnancy, delivery, and baby was abstracted from the routine obstetric notes.

Similar to recent findings in adults, the child's systolic pressure was inversely related to birth weight and positively related to placental weight. Systolic pressure at 4 years increased by $1.2 \mathrm{~mm} \mathrm{Hg}$ for every SD decrease in the ratio of head circumference to length at birth, and by $1.1 \mathrm{~mm} \mathrm{Hg}$ for every SD decrease in ponderal index at birth. Mothers whose haemoglobin concentrations fell below $100 \mathrm{~g} / 1$ during pregnancy had children whose systolic pressures were on average $2.9 \mathrm{~mm} \mathrm{Hg}$ higher than the children of mothers with higher haemoglobin concentrations.

Patterns of placental weight, birth weight, head circumference, and length that are associated with high blood pressure in adults are also associated with higher blood pressure in 4 year old children. Identification of the intrauterine influences that lead to these patterns of fetal growth could lead to the primary prevention of hypertension.
\end{abstract}

Recent findings suggest that adult hypertension originates in fetal life. ${ }^{12}$ In a study of 50 year old men and women in Preston, England, systolic and diastolic pressure were strongly predicted by birth weight and placental weight, which had independent and opposing effects. ${ }^{2}$ Mean systolic pressure fell by $11 \mathrm{~mm} \mathrm{Hg}$ as birth weight increased from less than $2475 \mathrm{~g}$ to more than $3375 \mathrm{~g}$ and rose by $15 \mathrm{~mm} \mathrm{Hg}$ as placental weight increased from less than $450 \mathrm{~g}$ to more than $675 \mathrm{~g}$. The highest pressures and risk of hypertension were among people who had been small babies with large placentas. ${ }^{2}$ These associations, which were highly significant, were independent of gestational age, current body mass index, and alcohol intake.

These findings raise the question of whether the opposing relations of blood pressure with birth weight and placental weight are apparent in children today, and if so what is the timing and nature of the intrauterine influences. To examine this we have measured the blood pressures of 405 children, aged 4 years, born in a city in southern England, and related them to measurements at birth.
Methods

All singleton children born in hospital in the Salisbury health district between July 1984 and February 1985, and still resident in the district at the age of 4 years, were eligible for inclusion in the study. (All hospital deliveries in this health district are at a single hospital.) Four hundred subjects was estimated as the sample size needed to give $95 \%$ power to detect a difference in systolic pressure of $4 \mathrm{~mm} \mathrm{Hg}$ between two subgroups of equal size, using a test at the $5 \%$ level.

Information on the pregnancy and measurements at birth was abstracted from the haematology and maternity records, including parity, first and maximum systolic and diastolic blood pressures recorded, routine haematology, gestation (estimated from the last menstrual period or, if absent, ultrasound scan), birth length, weight, head circumference, and placental weight.

Children were visited at home by one of two field workers: neither had seen the obstetric data. The children's ages ranged from 4.0 to 4.9 years (median 4.2 years): $93 \%$ were visited between the ages of 4 and 4.5 years. The child's social and medical history was recorded on a questionnaire. Social class was allocated according to occupation of the father, or if absent, the mother. ${ }^{3}$ Members of the armed forces and housewives were not allocated to a social class. The blood pressure, height, and weight of the child and both parents were measured. After the subjects had rested for five minutes, blood pressure was measured on the left arm at the level of the heart, using an automated blood pressure recorder (Dinamapp model 18465X). Cuff size was chosen according to recommendations based on those of the American Heart Association ${ }^{4}$ : three measurements were taken at one minute intervals. Weight was measured on digital scales to the nearest $0 \cdot 1 \mathrm{~kg}$. Height was measured in the Frankfurt plane on a portable stadiometer to the nearest $\mathrm{mm}$. Before starting the study, the procedures for measurements were standardised and the fieldworkers trained. No important interobserver variation was found during checks at intervals throughout the study, in which repeat measurements were made on subjects selected from outside the study population.

\section{Results}

Of 638 eligible children, 206 (32\%) could not be traced at their last known address, or their parents did not reply to the letters of invitation, and $20(3 \%)$ declined to take part in the study.
Correspondence to: Dr Law.

Accepted 8 July 1991 
Seven children reported as having renal or cardiac disorders or other congenital abnormalities were excluded. There remained 405 mothers and children, 205 boys and 200 girls. Of these $395(98 \%)$ had haematological records and 376 (93\%) had obstetric information, although this was not complete in all cases. Altogether 347 (86\%) fathers were studied: 37 fathers $(9 \%)$ had never or no longer lived in the same household, $10(2 \%)$ were working away, and $11(3 \%)$ did not wish to participate.

The children's systolic pressure fell by a mean of $5.5 \mathrm{~mm} \mathrm{Hg}$ (95\% confidence interval (CI) 4.2 to 6.9 ) from the first to the third reading. The within child SD was $9 \cdot 2 \mathrm{~mm} \mathrm{Hg}$. We present the analysis of the average of the three systolic pressure measurements. Neither age or sex of child, room temperature, month and time of day, or time since last meal, had a consistent effect on mean systolic pressure. The mean systolic pressure and weight at 4 years, and the mean gestation, placental weight, and size at birth are given in table 1.

SIZE AT BIRTH, PLACENTAL WEIGHT, GESTATION, AND WEIGHT AT 4 YEARS

Placental weight and weight, length, and head circumference at birth were adjusted for gestational age by linear regression. The simultaneous effects of weight at 4 years and adjusted birth weight and placental weight on systolic pressure were examined by multiple regression (table 2). Variables were grouped into approximate fourths so that we could explore non-linear variation of systolic pressure with each variable. The lowest fourth was set as the baseline and the systolic pressure in each group is given as its difference from this. Systolic pressure rose with increasing weight at 4 years with a pronounced rise in the heaviest group. Pressure fell with increasing birth weight and rose with placental weight: the average systolic pressure in children whose birth weight exceeded $3600 \mathrm{~g}$ was $2.6 \mathrm{~mm} \mathrm{Hg}$ (95\% CI -0.8 to 6.0 ) below that of children whose birth weights were $3000 \mathrm{~g}$ or less. Children whose placental weights were greater than $750 \mathrm{~g}$ had average pressures of $2.6 \mathrm{~mm} \mathrm{Hg}(95 \% \mathrm{CI}-0.8$ to 6.0$)$ above those whose placental weights were $550 \mathrm{~g}$ or less.

We further examined the association of systolic blood pressure with size at birth by analysing length and head circumference at birth after adjustment for gestational age. Children whose head circumferences had been in the lowest fourth $(\leqslant 33.5 \mathrm{~cm})$ had pressures which were $1 \cdot 3(95 \% \mathrm{CI}-2 \cdot 1$ to 4.7$) \mathrm{mm} \mathrm{Hg}$ above those whose head circumferences had been in the highest fourth $(>35.5 \mathrm{~cm})$. Children
Table 2 The simultaneous effects of weight at 4 years, birth weight, ${ }^{*}$ and placental weight ${ }^{*}$ on systolic pressure, expressed as mean difference (95\% CI) from the baseline

\begin{tabular}{|c|c|c|}
\hline & No & Systolic pressure $(\mathrm{mm} \mathrm{Hg})$ \\
\hline $\begin{array}{l}\text { Weight at } 4 \text { years }(\mathrm{kg}) \text { : } \\
\begin{array}{l}\leqslant 16.5 \\
-17.5 \\
-18.5 \\
>18.5\end{array}\end{array}$ & $\begin{array}{r}108 \\
92 \\
66 \\
98\end{array}$ & $\begin{array}{l}0.0 \text { (baseline) } \\
0.1(-2.6 \text { to } 2.9) \\
0.3(-2.7 \text { to } 3.4) \\
3.7(0.8 \text { to } 6.5)\end{array}$ \\
\hline $\begin{array}{l}\text { Birth weight (g): } \\
\quad \leqslant 3000 \\
-3300 \\
-3600 \\
>3600\end{array}$ & $\begin{array}{r}75 \\
102 \\
82 \\
105\end{array}$ & $\begin{array}{l}0.0 \text { (baseline) } \\
-0.8(-3.7 \text { to } 2 \cdot 2) \\
-0.9(-4.1 \text { to } 2 \cdot 4) \\
-2.6(-6.0 \text { to } 0.8)\end{array}$ \\
\hline $\begin{array}{l}\text { Placental weight }(\mathrm{g}) \text { : } \\
\leqslant 550 \\
-650 \\
-750 \\
>750\end{array}$ & $\begin{array}{r}96 \\
102 \\
83 \\
83\end{array}$ & $\begin{array}{r}0.0 \text { (baseline) } \\
-0.1(-3.0 \text { to } 2.7) \\
0.6(-2.5 \text { to } 3.7) \\
2.6(-0.8 \text { to } 6.0)\end{array}$ \\
\hline
\end{tabular}

*Birth weight and placental weight are adjusted for gestational age.

whose lengths had been in the lowest fourth $(\leqslant 49.5 \mathrm{~cm})$ had pressures that were $1.4(95 \% \mathrm{CI}$ -1.8 to 4.6 ) below those whose lengths had been in the highest fourth $(>52.5 \mathrm{~cm})$. Because of the opposing relations of systolic pressure to head circumference and length, mean systolic pressure rose as the ratio of head circumference to length decreased. A decrease in the ratio of $1 \mathrm{SD}(0.03)$ was associated with a $1.2 \mathrm{~mm} \mathrm{Hg}$ $(95 \% \mathrm{CI} 0 \cdot 1$ to $2 \cdot 2)$ increase in systolic pressure. We examined the relations of systolic pressure to birth weight and length using the ponderal index (weight/length ${ }^{3}$ ). Systolic pressure fell as the ponderal index at birth increased. An increase in ponderal index of $1 \mathrm{SD}\left(3.1 \mathrm{~kg} / \mathrm{m}^{3}\right)$ was associated with a $1 \cdot 1 \mathrm{~mm} \mathrm{Hg}(95 \% \mathrm{CI} 0 \cdot 1$ to $2 \cdot 1)$ decrease in systolic pressure.

MATERNAL BLOOD PRESSURE, HEIGHT, HAEMOGLOBIN CONCENTRATION, AND SMOKING The mean (SD) systolic pressure of mothers, measured when the child was aged 4 years, was $120.1(13.5) \mathrm{mm} \mathrm{Hg}$. The children's mean systolic pressure rose as the mother's systolic pressure increased (table 3). There was a similar relation with the mothers' maximum systolic pressure during pregnancy. As would be expected the mothers' blood pressure at the time of the survey and during pregnancy were strongly related.

Table 3 shows the relation of maternal variables to the children's systolic pressure which is given both unadjusted and adjusted (by linear regression) for its two main correlates, child's weight and mother's systolic pressure. The mean (SD) maternal height was $162.6(5 \cdot 9)$ $\mathrm{cm}$. Although the children of the smallest

Table 1 Characteristics of the sample by sex

\begin{tabular}{|c|c|c|c|c|}
\hline & \multicolumn{2}{|c|}{ Boys } & \multicolumn{2}{|c|}{ Girls } \\
\hline & No & Mean $(S D)$ & No & Mean $(S D)$ \\
\hline $\begin{array}{l}\text { Birth weight }(\mathrm{g}) \\
\text { Placental weight }(\mathrm{g}) \\
\text { Length at birth }(\mathrm{cm}) \\
\text { Head circumference at birth }(\mathrm{cm}) \\
\text { Gestation (weeks) } \\
\text { Weight at } 4 \text { years }(\mathrm{kg}) \\
\text { Systolic blood pressure (mm } \mathrm{Hg})\end{array}$ & $\begin{array}{l}205 \\
185 \\
181 \\
183 \\
205 \\
205 \\
205\end{array}$ & $\begin{array}{r}3391(576) \\
662(192) \\
51 \cdot 5(2 \cdot 6) \\
34 \cdot 8(1 \cdot 4) \\
40 \cdot 1(1 \cdot 7) \\
17 \cdot 8(2 \cdot 2) \\
105 \cdot 7(9 \cdot 7)\end{array}$ & $\begin{array}{l}200 \\
181 \\
180 \\
182 \\
198 \\
200 \\
200\end{array}$ & $\begin{array}{r}3342(495) \\
653(149) \\
50 \cdot 8(2 \cdot 4) \\
34 \cdot 3(1 \cdot 4) \\
40 \cdot 2(1 \cdot 6) \\
17 \cdot 3(2 \cdot 2) \\
105 \cdot 0(9 \cdot 9)\end{array}$ \\
\hline
\end{tabular}


mothers had the highest pressures, there was no overall trend with mother's height (table 3).

We examined the lowest haemoglobin concentrations and mean corpuscular volumes for each mother during pregnancy. We defined anaemia by a commonly used clinical definition of a haemoglobin value below $100 \mathrm{~g} / \mathrm{l}$. We also divided haemoglobin concentrations at $110 \mathrm{~g} / \mathrm{l}$; this is the World Health Organisation's (WHO) defining concentration for pregnancy anaemia. ${ }^{5}$ The children of anaemic mothers (haemoglobin below $100 \mathrm{~g} / \mathrm{l}$ ) had unadjusted systolic pressures which were, on average, $2.9 \mathrm{~mm} \mathrm{Hg}$ (95\% CI -0.4 to $6 \cdot 3$ ) higher than those of other children (table 3). The adjusted systolic pressures were also highest in children of anaemic mothers. The children of mothers with mean corpuscular volumes of $80 \mathrm{fl}$ or less $(\mathrm{n}=33)$ had systolic pressures which were, on average, $2.2 \mathrm{~mm} \mathrm{Hg}$ $(95 \% \mathrm{CI}-1 \cdot 3$ to $5 \cdot 7)$ higher than those of other children.

Birth weight fell from an average of $3377 \mathrm{~g}$ in mothers who did not smoke during pregnancy to $3178 \mathrm{~g}$ in mothers who smoked more than 20 cigarettes a day. However, the children's systolic pressures were not associated with their mother's smoking history, parity, or age (table 3 ).

MOTHERS' AND FATHERS' BLOOD PRESSURES

The mean (SD) of the fathers' systolic pressure at the time of the study was $131.8(14.0) \mathrm{mm}$ Hg. Where both parents' blood pressures were recorded, we examined the separate relation of the child's pressure with its parents. The children's mean systolic pressure, adjusted for weight, rose by $1.2 \mathrm{~mm} \mathrm{Hg}(95 \%$ CI 0.5 to 1.9$)$ for every $10 \mathrm{~mm} \mathrm{Hg}$ increase in mothers' systolic pressure, and by $0.7 \mathrm{~mm} \mathrm{Hg}(95 \% \mathrm{CI}$ 0.0 to 1.4 ) for every $10 \mathrm{~mm} \mathrm{Hg}$ increase in fathers' systolic pressure. The corresponding figures for first born children were 1.8 (95\% CI 0.6 to 2.9$)$ and $1.9(95 \% \mathrm{CI} 0.7$ to 3.1$)$ and for later born children were $0.8(95 \% \mathrm{CI}-0.1$ to $1 \cdot 7)$ and $0.1(95 \% \mathrm{CI}-0.8$ to 0.9$)$.

\section{SOCIAL CLASS}

Children in social classes I and II had lower systolic pressures (table 4). Haemoglobin con-

Table 3 Mean children's systolic pressure ( $\mathrm{mm} \mathrm{Hg}$ ) unadjusted and adjusted both for children's weight at 4 years and for mother's systolic pressure

\begin{tabular}{|c|c|c|c|}
\hline & No & Unadjusted* & Adjusted ${ }^{*}$ \\
\hline $\begin{array}{l}\text { Total } \\
\text { Mother's systolic pressure when child aged } 4 \text { years }(\mathrm{mm} \mathrm{Hg} \text { ): } \\
\leqslant 110 \\
-120 \\
-130 \\
>130\end{array}$ & $\begin{array}{r}405 \\
99 \\
128 \\
96 \\
82\end{array}$ & $\begin{array}{l}105 \cdot 3 \\
103 \cdot 3 \\
104 \cdot 9 \\
105 \cdot 1 \\
108 \cdot 7\end{array}$ & $105 \cdot 2$ \\
\hline $\begin{array}{l}\text { Mother's height }(\mathrm{cm}): \\
\leqslant 159 \\
-163 \\
-167 \\
>167\end{array}$ & $\begin{array}{r}103 \\
106 \\
99 \\
94\end{array}$ & $\begin{array}{l}105 \cdot 9 \\
104 \cdot 5 \\
104 \cdot 9 \\
105 \cdot 8\end{array}$ & $\begin{array}{l}106 \cdot 0 \\
104 \cdot 7 \\
104 \cdot 9 \\
104 \cdot 9\end{array}$ \\
\hline $\begin{array}{l}\text { Lowest haemoglobin during pregnancy }(\mathrm{g} / \mathrm{l}) \\
<100 \\
-109 \\
-119 \\
\geqslant 120\end{array}$ & $\begin{array}{r}36 \\
88 \\
164 \\
106\end{array}$ & $\begin{array}{l}108 \cdot 1 \\
105 \cdot 8 \\
104 \cdot 8 \\
105 \cdot 2\end{array}$ & $\begin{array}{l}108 \cdot 1 \\
105 \cdot 9 \\
104 \cdot 7 \\
104 \cdot 6\end{array}$ \\
\hline $\begin{array}{l}\text { Cigarettes smoked/day during pregnancy: } \\
0 \\
-10 \\
-20 \\
>20\end{array}$ & $\begin{array}{r}323 \\
34 \\
28 \\
19\end{array}$ & $\begin{array}{l}105 \cdot 1 \\
106 \cdot 2 \\
106 \cdot 1 \\
105 \cdot 2\end{array}$ & $\begin{array}{l}105 \cdot 0 \\
105 \cdot 9 \\
105 \cdot 6 \\
106 \cdot 1\end{array}$ \\
\hline $\begin{array}{l}\text { Parity: } \\
\text { First born } \\
\text { Later born }\end{array}$ & $\begin{array}{l}152 \\
253\end{array}$ & $\begin{array}{l}105 \cdot 0 \\
105.5\end{array}$ & $\begin{array}{l}104 \cdot 9 \\
105 \cdot 3\end{array}$ \\
\hline $\begin{array}{l}\text { Mother's age at birth of child (years): } \\
\leqslant 25 \\
-28 \\
-31 \\
>31\end{array}$ & $\begin{array}{r}92 \\
106 \\
92 \\
115\end{array}$ & $\begin{array}{l}105 \cdot 2 \\
105 \cdot 9 \\
105 \cdot 2 \\
104 \cdot 9\end{array}$ & $\begin{array}{l}104 \cdot 9 \\
106 \cdot 3 \\
104 \cdot 8 \\
104 \cdot 5\end{array}$ \\
\hline
\end{tabular}

*SD of unadjusted values is $\mathbf{9 \cdot 8}$ and of adjusted values is $\mathbf{9 \cdot 4}$

Table 4 Children's systolic pressure and mother's lowest haemoglobin concentration and mean corpuscular volume during pregnancy, by social class

\begin{tabular}{lclll}
\hline Social class & No & $\begin{array}{l}\text { Mean (unadjusted) } \\
\text { children's pressure } \\
(\text { mm Hg) }\end{array}$ & $\begin{array}{l}\text { Lowest } \\
\text { haemoglobin } \\
(\mathrm{g} / \mathrm{l})\end{array}$ & $\begin{array}{l}\text { Mean* } \\
\text { corpuscular } \\
\text { volume }(f)\end{array}$ \\
\hline I & 34 & $103 \cdot 6$ & 115 & $86 \cdot 8$ \\
II & 100 & $104 \cdot 7$ & 114 & $86 \cdot 8$ \\
III non-manual & 43 & $105 \cdot 4$ & 111 & $87 \cdot 0$ \\
III manual & 121 & $106 \cdot 0$ & 113 & $85 \cdot 3$ \\
IV and V & 51 & $105 \cdot 8$ & 111 & $85 \cdot 2$ \\
Total & 349 & $105 \cdot 3$ & 113 & $86 \cdot 1$ \\
(SD) & & $9 \cdot 6$ & 10 & $4 \cdot 6$ \\
\hline
\end{tabular}

${ }^{*}$ Haematological indices were not known for 10 subjects. 
centration during pregnancy was highest in social class I and II. Mean corpuscular volume was highest in mothers of social class I, II and III non-manual (table 4).

\section{SIMULTANEOUS EFFECT OF FETAL SIZE AND}

MATERNAL INFLUENCES

Table 5 shows the simultaneous effects of child and fetal size and maternal variables on the children's systolic pressure. Weight at 4 years, placental weight, ponderal index at birth, mother's systolic pressure, and haemoglobin concentration during pregnancy all had independent relations with systolic pressure. We examined the relationship of mean diastolic pressure to the variables shown in table 5 . The relations were similar to those with systolic pressure but the mean differences were smaller and none reached significance.

When systolic pressure was regressed on the same variables expressed continuously, rather than in groups, the results were comparable (table 6).

\section{Discussion}

We have examined the relations of systolic pressure to maternal and fetal influences in a series of 4 year old children, born in a maternity

Table 5 Simultaneous effects of weight at 4 years, size at birth, ${ }^{*}$ and maternal influences on systolic pressure, expressed as mean difference $(95 \% \mathrm{CI})$ from the baseline

\begin{tabular}{|c|c|c|}
\hline & No & Systolic pressure $(\mathrm{mm} \mathrm{Hg})$ \\
\hline $\begin{array}{l}\text { Weight at } 4 \text { years }(\mathrm{kg}) \text { : } \\
\leqslant 16.5 \\
-17.5 \\
-18.5 \\
>18.5\end{array}$ & $\begin{array}{r}103 \\
85 \\
60 \\
95\end{array}$ & $\begin{array}{l}0.0 \text { (baseline) } \\
-0 \cdot 1(-3 \cdot 0 \text { to } 2 \cdot 7) \\
0.0(-3 \cdot 2 \text { to } 3 \cdot 1) \\
2.6(-0.2 \text { to } 5 \cdot 4)\end{array}$ \\
\hline $\begin{array}{l}\text { Placental weight }(\mathrm{g}) \text { : } \\
\leqslant 550 \\
-650 \\
-750 \\
>750\end{array}$ & $\begin{array}{l}90 \\
97 \\
77 \\
79\end{array}$ & $\begin{array}{l}0.0 \text { (baseline) } \\
0.3(-2 \cdot 6 \text { to } 3 \cdot 1) \\
1 \cdot 2(-1.9 \text { to } 4 \cdot 3) \\
2 \cdot 3(-0.8 \text { to } 5 \cdot 3)\end{array}$ \\
\hline $\begin{array}{l}\text { Ponderal index }\left(\mathrm{kg} / \mathrm{m}^{3}\right) \text { : } \\
<23 \\
-25 \\
-27 \cdot 5 \\
>27.5\end{array}$ & $\begin{array}{l}79 \\
86 \\
94 \\
84\end{array}$ & $\begin{aligned} & 0.0 \text { (baseline) } \\
&-0.8(-3.8 \text { to } 2.3) \\
&-2.4(-5.4 \text { to } 0.5) \\
&-3.9(-7.0 \text { to }-0.9)\end{aligned}$ \\
\hline $\begin{array}{l}\text { Mother's systolic pressure } \\
<110 \\
-120 \\
-130 \\
>130\end{array}$ & $\begin{array}{l}(\underset{81}{\operatorname{mm}} \mathrm{Hg}): \\
109 \\
81 \\
72\end{array}$ & $\begin{array}{l}0.0 \text { (baseline) } \\
1.6(-1.2 \text { to } 4.4) \\
0.9(-2.2 \text { to } 3.9) \\
5.0(1.9 \text { to } 8.1)\end{array}$ \\
\hline $\begin{array}{l}\text { Lowest haemoglobin }(\mathrm{g} / \mathrm{l}) \text { : } \\
\quad<100 \\
-109 \\
-119 \\
\geqslant 120\end{array}$ & $\begin{array}{r}30 \\
77 \\
141 \\
95\end{array}$ & $\begin{aligned} 2.8(-3.4 \text { to } 1.7) \\
0.3(-2.7 \text { to } 3.3) \\
-0.9(-1.3 \text { to } 6.8) \\
0.0 \text { (baseline) }\end{aligned}$ \\
\hline
\end{tabular}

${ }^{*}$ Birth weight, length, and placental weight are adjusted for gestational age. unit which provides all hospital obstetric care for one health district. The children were selected only by their continuing residence in the health district. Blood pressure was measured with an automated recorder in the child's home by a standarised procedure. Efforts were made to minimise stress and disturbance to the child before and during measurement, but there was still considerable within child variation in systolic pressure, including a pronounced order effect. The mean (SD) of the third reading, $102.7 \mathrm{~mm} \mathrm{Hg}(11.6)$, was $5.4 \mathrm{~mm} \mathrm{Hg}$ above the 50th centile in the British standards, which were measured with a sphygmomanometer. ${ }^{6}$ In keeping with other studies we have used the average of the readings in our analysis. Average systolic pressure was positively related to weight at 4 years; this is in agreement with other studies in Britain ${ }^{167}$ and North America. ${ }^{8}$

The opposing relations of systolic pressure to birth weight and placental weight demonstrated in 50 year old men and women in Preston ${ }^{2}$ were present in 4 year old children, though weaker. Systolic pressure at age 4 was inversely related to birth weight. This was independent of gestation and implies an association with reduced fetal growth, which is consistent with findings in 10 year old children in a national British cohort. ${ }^{1}$ However, birth weight is a summary measure of fetal growth, which includes head size, length, and fatness. Further examination showed that systolic pressure was related to failure of head growth in relation to length and to a low ponderal index. Analysis of the Preston data has shown the same associations in adults (unpublished). To our knowledge neither of these associations with children's blood pressure has been described before. Both were significant. The nature of intrauterine influences that cause reduced head circumference and weight in relation to length are unknown and require further study.

The highest systolic pressures were found in children who had been small babies with large placentas, although the magnitude of the relations between pressure and placental and fetal size were smaller than in adults, even allowing for the smaller variation in children's blood pressure. Furthermore these relations were at the margin of significance and require confirmation in other samples of children. The causes of high placental weight and discordance between placental and birth weight are mostly unknown. Smoking during pregnancy is associated with reduced placental weight, though with a relatively greater decrease in birth weight than placental weight, and thus discordance between the two. ${ }^{9}$ We found no relation between

Table 6 Simultaneous effects of weight at 4 years, size at birth, ${ }^{*}$ and maternal influences, expressed as continuous variables, on systolic pressure

\begin{tabular}{|c|c|c|c|}
\hline & $\begin{array}{l}\text { Regression } \\
\text { slope }\end{array}$ & $95 \% C I$ & p Value \\
\hline $\begin{array}{l}\text { Weight at } 4 \text { years }(\mathrm{kg}) \\
\text { Placental weight }(\mathrm{g}) \\
\text { Ponderal index }\left(\mathrm{kg} / \mathrm{m}^{3}\right) \\
\text { Mother's systolic pressure }(\mathrm{mm} \mathrm{Hg}) \\
\text { Lowest haemoglobin }(<100 \mathrm{~g} / \mathrm{l} v \geqslant 100 \mathrm{~g} / \mathrm{l})\end{array}$ & $\begin{array}{c}0 \cdot 65 \\
0.003 \\
-0.41 \\
0 \cdot 12 \\
-3 \cdot 1\end{array}$ & $\begin{array}{l}0.17 \text { to } 1.13 \\
-0.003 \text { to } 0.009 \\
-0.74 \text { to }-0.09 \\
0.04 \text { to } 0.19 \\
-6.7 \text { to } 0.5\end{array}$ & $\begin{array}{c}<0.01 \\
0.4 \\
<0.05 \\
<0.002 \\
0.09\end{array}$ \\
\hline
\end{tabular}

${ }^{*}$ Birth weight, length, and placental weight are adjusted for gestational age. 
maternal smoking and the children's blood pressure (table 3).

The children's blood pressure was more closely related to the mothers' than the fathers' systolic pressure. This has been found before and has been ascribed to $\mathrm{X}$ linked genes. ${ }^{10}{ }^{11}$ Another possibility is that higher blood pressure in a mother reflects her own fetal experience, which in turn influences the intrauterine environment she provides for her children. Studies of the Dutch famine have shown that women whose mothers were malnourished during pregnancy themselves had babies with retarded intrauterine growth. ${ }^{12}$ The relation between the child's and father's pressure was found only in first born children, which suggest that in the later born the genetic contribution of the father's pressure is overridden by other factors. Our data do not allow further resolution of this.

We found that a maternal haemoglobin concentration below $100 \mathrm{~g} / \mathrm{l}$ was associated with higher systolic pressure in the child, though this was not significant (table 3). Although haemoglobin may fall in pregnancy as a result of haemodilution, there is evidence that a haemoglobin concentration below $100 \mathrm{~g} / 1$ is usually associated with iron deficiency. ${ }^{13}$ The lower mean corpuscular volumes and haemoglobin concentration in the lower social classes in our study are consistent with this (table 4). Although Salisbury has a relatively high socioeconomic status, $31 \%$ of mothers had haemoglobin concentrations below $110 \mathrm{~g} / \mathrm{l}$, the WHO definition of anaemia in pregnancy. 5

Anaemia is associated with increased placental size, ${ }^{14}$ but this did not appear to be the sole mechanism of its relation with increased blood pressure, which was still present when considered simultaneously with the effects of placental weight (table 5). The rise in a child's blood pressure that is associated with anaemia could be a response to reduced maternal oxygen carrying capacity or a consequence of nutritional deficiency causing both anaemia and raised blood pressure. Findings in a rural community in the Gambia, West Africa, support a link between maternal nutrition and children's blood pressure. Failure of mothers to gain weight during the last trimester was associated with increased blood pressure in the child at 8 to 10 years. ${ }^{15}$ Better maternal nutrition could explain the lower pressures recently found in 5 to 7 year old children in Guildford, a British town with relatively high socioeconomic status. ${ }^{16}$

Patterns of placental weight, birth weight, head circumference, and length that are associated with high blood pressure in adults are also associated with higher blood pressure in 4 year old children. We are carrying out a further study in another part of Britain to confirm this. Identification of the intrauterine influences which lead to these patterns of fetal growth could lead to the primary prevention of hypertension.

We are grateful to the obstetric and community health departments, Odstock Hospital, and the medical records department, Salisbury General Infirmary, for their cooperation, Mrs Zwartouw and Mrs $\mathrm{H}$ Howes for the fieldwork, and Mr Pau Winter and Mr Graham Wield for computing.

1 Barker DJP, Osmond C, Golding J, Kuh D, Wadsworth MEJ. Growth in utero, blood pressure in childhood and adult life, and mortality from cardiovascular disease. $B M \mathcal{F}$ adult life, and mort

2 Barker DJP, Bull AR, Osmond C, Simmonds SJ. Fetal and placental size and risk of hypertension in adult life. $B M \mathcal{J}$ 1990;301:259-62.

3 Office of Population Censuses and Surveys. Classifications of occupations. London: HMSO, 1980.

4 Prineas RJ, Gillum RF, Horobe H, Hanna PJ. The Minneapolis children's blood pressure study. Part 1: standards of measurement for children's blood pressure. $\mathcal{f}$ Hyperten 1980;2(suppl 1):18-24

5 World Health Organisation Technical Report Series. Nutritional anaemias. Geneva: World Health Organisation, 1968 , No 405

6 de Swiet M, Fayers P, Shinebourne E. Blood pressure in four and five year old children. The effects of environment and

7 Whincup PH, Cook DG, Shaper AG. Early influences on blood pressure: a study of children aged 5-7 years. BMF blood pressure: a

8 Voors AW, Webber LS, Frerichs RR, Berenson GS. Body height and body mass as determinants of basal blood pressure in children-the Bogalusa heart study. $A m$ f Epidemiol 1977;106:101-8.

9 Godfrey KM, Redman CWG, Barker DJP, Osmond C. The effect of maternal anaemia and iron deficiency on the ratio of fetal weight to placental weight. Br $\mathcal{F}$ Obstet Gynaecol 1991 (in press).

10 Bengtsson B, Thulin T, Schersten B. Familial resemblance in casual blood pressure-a maternal effect? Clin Sc 1979;57: $279-94$.

11 Gerson LW, Fodor JG. Family aggregation of high blood pressure groups in two Newfoundland communities. Can f Public Health 1975;66:294-9.

12 Lumey H. Obstetric performance of women after in utero exposure to the Dutch famine (1944-1945). New York: Columbia to the Dutch famine (1944-1945)

13 de Leeuw NKM, Lowenstein L, Hsieh YS. Iron deficiency hydremia in normal pregnancy. Medicine 1966;45:291-315.

14 Beischer NA, Sivasamboo R, Vohra S, Silpisornkosal S, Reid Beischer NA, Sivasamboo R, Vohra S, Silpisornkosal S, Reid
S. Placental hypertrophy in severe pregnancy anaemia. foumal of Obstetrics and Gynaecology of the British Commonwealth 1970;77:398-409.

15 Margetts B, Rowland MGM, Foord FA, Cruddas AM, Cole TJ, Barker DJP. The relation of maternal weight to the blood pressure of Gambian children. Int $\mathcal{F}$ Epidemiol 1991 (in press).

16 Whincup PH, Cook DG, Shaper AG, MacFarlane DJ, Walker M. Blood pressure in British children: associations with adult blood pressure and cardiovascular mortality. 